九州大学学術情報リポジトリ

Kyushu University Institutional Repository

Toxicity of Selective Insecticides to Neochrysocharis formosa (Westwood) (Hymenoptera: Eulophidae), a Parasitoid of the American Serpentine Leafminer Liriomyxa trifolii (Burgess) (Diptera: Agrizomydae)

Tran, Dang Hoa

Laboratory of Insect Natural Enemies, Division of Biological Control, Department of Applied Genetics and Pest Management, Graduate School of Bioresource and Bioenvironmental

Sciences, Kyushu University

Takagi, Masami

Takasu, Ke i j i

Laboratory of Bioresources and Management, Division of Bioresources and Management, Department of Applied Genetics and Pest Management, Faculty of Agriculture, Kyushu University

https://doi.org/10.5109/4627

出版情報：九州大学大学院農学研究院紀要. 50 (1)，pp. 109-124，2005-02-01. Faculty of Agriculture, Kyushu University

バージョン :

権利関係 : 
J. Fac. Agr., Kyushu Univ., 50 (1), 109-118 (2005)

\title{
Toxicity of Selective Insecticides to Neochrysocharis formosa (Westwood) (Hymenoptera: Eulophidae), a Parasitoid of the American Serpentine Leafminer Liriomyza trifolii (Burgess) (Diptera: Agrizomydae)
}

\author{
Dang Hoa TRAN ${ }^{1}$, Masami TAKAGI* and Keiji TAKASU ${ }^{2}$ \\ Laboratory of Insect Natural Enemies, Division of Biological Control, Department of \\ Applied Genetics and Pest Management, Faculty of Agriculture, \\ Kyushu University, Fukuoka 812-8581, Japan \\ (Received May 19, 2004 and accepted November 11, 2004)
}

\begin{abstract}
The susceptibilities of Neochrysocharis formosa, a larval parasitoid of the American serpentine leafminer Liriomyza trifolii, to three insecticides (imidacloprid, pymetrozine and lufenuron) were investigated in the laboratory. Individual parasitoids were placed in the grass vials whose internal surface was coated with the insecticides. For $24 \mathrm{~h}$ exposure, the $\mathrm{LC}_{5 n}$ values were $0.033 \mu \mathrm{g} / 0.5 \mathrm{ml}$ for imidacloprid, $75.57 \mu \mathrm{g} / 0.5 \mathrm{ml}$ for pymetrozine and $0.417 \mu \ell / 0.5 \mathrm{ml}$ for lufenuron. For imidacloprid and lufenuron, these values were 775.5 and 14.9 times lower than the recommended concentrations, respectively. Even in the concentrations lower than the $\mathrm{LC}_{\mathrm{in}}$, parasitoid survival rapidly decreased with time, and the longevity of parasitoid females was also reduced. These results suggested that all of imidacloprid, pymetrozine and lufenuron were harmful to $N$. formosa.
\end{abstract}

\section{INTRODUCTION}

Insect pest management relies on both natural enemies and insecticides as is a typical of many agroecosystems. Pesticides have long overshadowed importance of natural enemies in pest management programs. The frequent use of insecticides to manage these pests may destroy natural enemies and encourage pest resurgence or a secondary pest outbreak. Pesticides can exert two different types of effects on natural enemies. Lethal effects are expressed as acute or chronic mortality arising from contact with a pesticide. Sublethal effects, in contact, are often chronic and are expressed as some change in the insect's life history attributes, such as its fecundity, longevity, developmental time, egg viability, consumption rates, behavior, and so forth (Ruberson et al., 1998). Lethal effects are manifested as short-term mortality and often the greatest impact on natural enemies (Johnson and Tabashnik, 1999).

Natural enemies and pesticides can be effectively integrated with adequate knowledge of the pesticides to be used and its effects on natural enemy populations (Jepson, 1989; Croft, 1990, Greathead, 1995). Understanding the impact of pesticides usually

1 Laboratory of Insect Natural Enemies, Division of Biological Control, Department of Applied Genetics and Pest Management, Graduate School of Bioresource and Bioenvironmental Science, Kyushu University

2 Laboratory of Bioresources and Management, Division of Bioresources and Management, Department of Applied Genetics and Pest Management, Faculty of Agriculture, Kyushu University

* Corresponding author (E-mail: mtakagi@agr.kyushu-u.ac.jp) 
requires a variety of bioassays to determine the selectivity of pesticides against the natural enemies, and their role in the ecology of pest management programs (Croft, 1990, Hassan, 1989). Pioneering work has been carried out in Europe to develop standardized tests for measuring the toxicity of pesticides to beneficial arthropods using a sequential procedure progressing from exposure in the laboratory to field trials (Hassan, 1989).

Liriomyza trifolii (Burgess) (Diptera: Agromyzidae), native to North and South America, is a serious pest of numerous ornamental and vegetable crops worldwide (Parrella, 1987; Spencer, 1989, 1990). Over 40 species of parasitoids have been recovered from Liriomyza spp. leafminers in the world (Waterhouse and Norris, 1987), including 27 species in Japan (Konishi, 1998). Neochrysocharis formosa (Westwood) (Hymenoptera: Eulophidae) is an endoparasitoid that attacks larvae of leafminers and eggs of sawflies (Yoshimoto, 1978; Hasson, 1990, 1995). In Kyushu, N. formosa is predominant among parasitoids attacking $L$. trifolii, and has been recognized as an effective biological agent of leafminers in tomato, bean and eggplant (Saito et al., 1996; Arakaki et al., 1998; Ohno et al., 1999 and Maryana, 2000). Therefore, inundative release of $N$. formosa show promise for suppression of $L$. trifolii in those crops where insecticide use has been reduced.

In this study, a series of tests were conducted on females of $N$. formosa to determine their sensitivities to different insecticides (imidacloprid, pymetrozine and lufenuron). Imidacloprid and pymetrozine are commonly used for controlling sucking pests such as Aphis gossypi, Brevioryne brassicaei, Bemisia argentifolii, Thrips tabaci and Caliothrips brasiliensis (Bethke and Redak, 1997; Marquini et al., 2002; Sechser et al., 2002; Ester et al., 2003). Lufenuron is currently available for lepidopteran pests including Spodoptera littoralis, Phthorimaea operculella and Lacanobia oleracae (Javaid et al., 1999; Edomwande et al., 2000; Whiting et al., 2000; Butter et al., 2003). These pests and the leafminers often co-exist in fields of various vegetables and ornamental crops, including tomato, melon, cucumbers, eggplants, green pepper, peach, chrysanthemum, apple and strawberry (Sibanda et al., 2000; van Lenteren, 2000; Marquini et al., 2002). The purpose was to determine which insecticide was least toxic to the parasitoid, and therefore best suited for use in an IPM program.

\section{MATERIALS AND METHODS}

\section{Insect pest}

L. trifolii was reared on the kidney bean, Phaseolus vulgaris L., in the same manner as described by Giang and Ueno (2002) and Tran et al. (2004). A single seed of this plant was sown in a plastic pot $\left(7.5 \mathrm{~cm}\right.$ in diameter) kept at $25^{\circ} \mathrm{C}$ and $60-70 \%$ humidity under constant light. One week after germination, a tray $(32 \mathrm{~cm} \times 44 \mathrm{~cm} \times 6 \mathrm{~cm})$ containing 24 potted plants was placed on a shelf $(200 \mathrm{~cm} \times 60 \mathrm{~cm} \times 50 \mathrm{~cm})$ covered with a fine nylon mesh. Leafminer adults were released inside the mesh and allowed to oviposit on the plants for $24 \mathrm{~h}$. Thereafter, the potted plants were maintained under the same conditions until all leafminer larvae feeding on the plants reach the last instar. The leaves containing final-instar larvae were cut off and kept in a polyethylene terephthalate (PET) bottle (1.51 in volume) to gain adult leafminers. 


\section{Parasitoid}

The asexual strain of the parasitoid $N$. formosa used for the present study originated from a culture that was reared from L. trifolli mines collected in August 1997 from Kagoshima Prefecture by the Fukuoka Agricultural Research Center, Fukuoka, Japan. This parasitoid was maintained with the final- instars of $L$. trifolii at $25^{\circ} \mathrm{C}$ with $60-70 \%$ humidity and 16L: 8D. Each leaf of kidney bean plants (15-20 cm in height) was infected with 30-50 second and third instar larvae of L. trifolii. For parasitization, 6 hostinfested plants and a piece of tissue paper $(2 \mathrm{~cm} \times 2 \mathrm{~cm})$ saturated with a honey solution were placed in a plastic cage $(35 \mathrm{~cm} \times 20 \mathrm{~cm} \times 25 \mathrm{~cm})$ covered with a fine nylon mesh. About 100-300 parasitoids were introduced into the cage. After exposure for $24 \mathrm{~h}$, these plants were relocated to a plastic container $(60 \mathrm{~cm} \times 50 \mathrm{~cm} \times 40 \mathrm{~cm})$ until pupation of the parasitoids (approximately 6 days after parasitism). The kidney bean leaves with parasitoid pupae were removed from the plant stems and placed into a PET bottle (1l in volume). Emergence of parasitoids was checked daily. Female wasps were provided honey immediately after emergence.

\section{Insecticides}

We tested the insecticides listed in Table 1 . They were selected on the basis of their current and potential use for the management of key insect pests on vegetable crops.

Table 1. Insecticides tested for toxicity to N. formosa

\begin{tabular}{|c|c|c|c|c|}
\hline Common name & $\begin{array}{l}\text { Trade } \\
\text { name }\end{array}$ & $\begin{array}{l}\text { Formu- } \\
\text { lation }\end{array}$ & $\begin{array}{c}\text { Recommended } \\
\text { concentrations } \\
\left(\mu \mathrm{g}^{\mathrm{b}} \text { or } \mu \ell \% 0.5 \mathrm{ml}\right)\end{array}$ & Main targets \\
\hline Imidacloprid & Admire & WP & $25^{b}$ & $\begin{array}{c}\text { Aphids, leafhoper, flea beetle, } \\
\text { whitefly. }\end{array}$ \\
\hline Pymetrozine & Chess & WP & $62.5^{1,}$ & Aphids, whitefly \\
\hline Lufenuron & Match & EC & $6.25^{\prime}$ & Lepidoptera, thrips, rust mites. \\
\hline
\end{tabular}

"EC, emulsifiable; WP, wettable power

\section{Bioassay}

Toxicity measurements were made by exposing parasitoids to insecticide coats on the inner surfaces on $20 \mathrm{ml}$ grass vials $(28 \mathrm{~mm} \times 60 \mathrm{~mm})$. The coats were prepared by pipetting $0.5 \mathrm{ml}$ insecticide solution with acetone into the vials, and manually rotating the vials on their sides until the solvent evaporated. The vials coated only acetone were used for control. Wasp females were individually placed in each vial along with a $1 \mathrm{~cm}$ square of cotton soaked in $30 \%$ honey in water. Exposed females were kept at $25^{\circ} \mathrm{C}, 60-70 \%$ humidity and 16L: 8D light period.

\section{Dose-response bioassay}

Preliminary tests were used to obtain the approximate $\mathrm{LC}_{50}$ for each insecticide. A $50 \mathrm{ml}$ stock solution was prepared for each insecticide with concentration reflecting recommended field rates by producers (Table 1). The solution was made by diluting insecticide with Acetone $300,99.5+\%$ (GC). A series of concentrations for each insecticide was 
made by adding acetone to a $1 \mathrm{ml}$ stock solution. The ranges of doses tested for each insecticide were: imidacloprid, 0.0125 to $2.5 \mu \mathrm{g} / \mathrm{vial}$; pymetrozine, 6.25 to $87.5 \mu \mathrm{g} / \mathrm{vial}$ and lufenuron, 0.301 to $6.25 \mu \mathrm{l} / \mathrm{vial}$. Mortality determinations were made $24 \mathrm{~h}$ after initial exposure. Twenty parasitoid females were tested at each insecticide concentration.

Time-response bioassay

Serial time- dose-response bioassays was used to determine response of the females to different doses of each insecticide in the glass vials. The ranges of doses tested for each insecticide were made by diluting insecticide with acetone until being dose equivalent to 1, 2, 5 and 10 times lower than $\mathrm{LC}_{50}$-dose obtained from the dose-response bioassays. Survival was determined at $24 \mathrm{~h}, 48 \mathrm{~h}, 72 \mathrm{~h}, 96 \mathrm{~h}$ and $120 \mathrm{~h}$ after initial exposure. Alive females were maintained and monitored daily until all wasps had died to determine their longevity. The piece of soaked cotton was replaced daily to provide fresh food to the female. Fifty females were tested at each insecticide concentration

\section{Data analysis}

Dose- response data were analyzed by probit analysis program PriProbit ver. 1.63 (Sakuma, M, 1998). Serial time- dose data were analyzed using the survival analysis, Kaplan-Meier test, JMP4J (SAS Institute Inc. 2000). The longevity of females was analyzed by a one-way ANOVA, and means were separated by Fisher's PLSD test, StatView ver. 5.0 (SAS Institute Inc. 1998).

\section{RESULTS}

\section{Dose-response}

Results of the probit analysis of dose response data $\left(\mathrm{LC}_{50}\right.$, slopes and intercepts of the dosage-mortality lines) for $N$. formosa females are given in Table 2. The data show a wide range in response to different insecticides. The ranges from most toxic (imidacloprid) to least toxic (pymetrozine) are 2,290-fold at the $\mathrm{LC}_{50}$ level. Imidaclopid and lufenuron were more specifically toxic to the females. $\mathrm{LC}_{50}$ values of lufenuron and imidaclopid were much lower than the recommended concentrations 14.9 and 757.5 times, respectively. For pymetrozine, $\mathrm{LC}_{50}$ value was a little higher than the recommended concentration.

Table 2. Probit parameters of dose respones of $N$. formosa

\begin{tabular}{|c|c|c|c|c|c|}
\hline Common name & Intercept" & Slope $^{a}$ & $\begin{array}{c}\mathrm{LC}_{\mathrm{sul}} \text { ( } \mu \mathrm{g} \text { or } \\
\mu \ell \% \text { vial) }\end{array}$ & $\chi$ & $\begin{array}{l}\text { Ratio: recommended } \\
\text { concentration/LC } \mathrm{C}_{5 \mathrm{l}}\end{array}$ \\
\hline Imidacloprid & $\begin{array}{c}2.73 \\
(0.35)\end{array}$ & $\begin{array}{c}1.84 \\
(0.28)\end{array}$ & $\begin{array}{c}0.033 \\
(0.021-0.045)\end{array}$ & $\begin{array}{c}9.13 \\
(6,0.167)\end{array}$ & 757.5 \\
\hline Pymetrozine & $\begin{array}{l}-4.86 \\
(0.94)\end{array}$ & $\begin{array}{c}2.59 \\
(0.53)\end{array}$ & $\begin{array}{c}75.59 \\
(62.01-101.74)\end{array}$ & $\begin{array}{c}11.93 \\
(6,0.130)\end{array}$ & 0.8 \\
\hline Lufenuron & $\begin{array}{c}0.85 \\
(0.12)\end{array}$ & $\begin{array}{c}2.26 \\
(0.44)\end{array}$ & $\begin{array}{c}0.417 \\
(0.244-0.57)\end{array}$ & $\begin{array}{c}5.95 \\
(5,0.311)\end{array}$ & 14.9 \\
\hline
\end{tabular}

" ( \pm standard error); " (95\% fiducial limits); " (df, p) 


\section{Time-response}

The cumulative survival in the present of insecticides depended on the duration of exposure (Fig. 1). When the females were exposed to treated insecticides, the cumulative survival decreased with time, and the survival was different between insecticide concentrations (imidaclopid: $\chi^{2}=146.1, d f=4, P<0.0001$; pymetrozine: $\chi^{*}=159.5, d f=4$, $P<0.0001$; lufenuron: $\chi^{2}=157.7, d f=4, P<0.0001$ ).

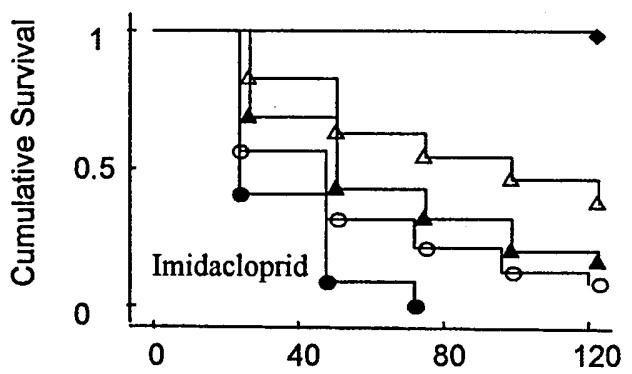
Acetone
$\triangle \mathrm{LC}_{50} / 10$
$\triangle \mathrm{LC}_{50} / 5$
$\circ \mathrm{LC}_{50} / 2$
- $\mathrm{LC}_{50}$
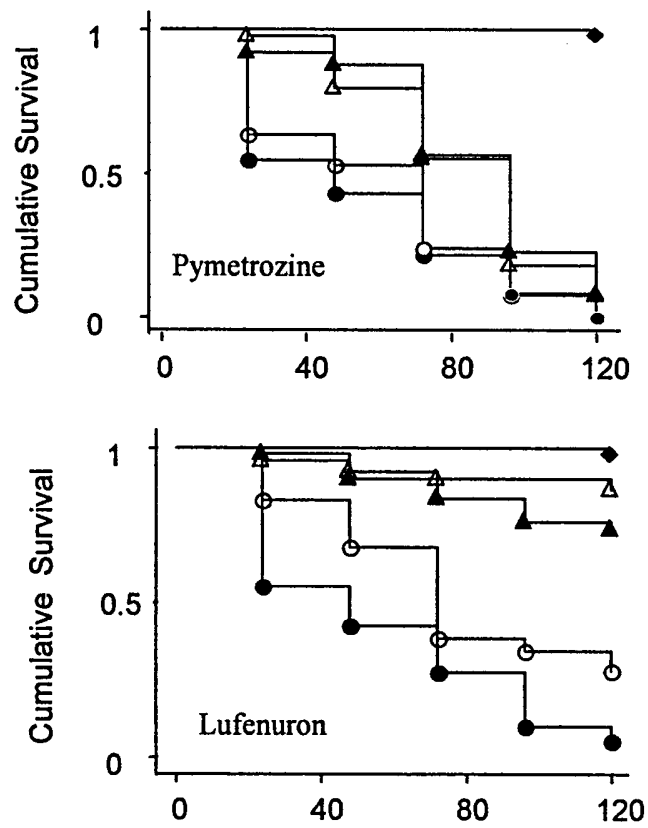

Exposure duration (hours)

Fig. 1. Cumulative survival of female $N$. formosa that survived treatments with different concentrations of imidaclopid $(\chi=146.1, d f=4, P<0.0001)$, pymetrozine $\left(\chi^{2}=159.5, d f=4, P<0.0001\right)$, lufenuron $\left(\chi^{\prime}=157.7, d f=\right.$ $4, P<0.0001)$. Survival Analysis: Kaplan- Meier test, JMP4J, SAS Institute 2000 . 
Exposure to all concentrations of imidaclopid and pymetrozine resulted in decreasing the cumulative survival. Meanwhile, exposure to lufenuron resulted in little effect on survival until a threshold was reached $\left(\mathrm{LC}_{51} / 5\right)$, whereby exposure to $\mathrm{LC}_{50}$ and $\mathrm{LC}_{51} / 2$ resulted in a high level of mortality within the first 5 days.

\section{Effect of different doses of insecticides on longevity}

When the females were exposed to treated insecticides, the mean longevity decreased with increasing concentration. The females' longevity in all insecticide treatments was shorter than control treatment (Table 3 ).

There were highly significant differences (imidaclopid, $F=51.2, d f=4,240, P<$ 0.0001 ; pymetrozine, $F=115.1, d f=4,216, P<0.0001$; lufenuron, $F=115.1, d f=4,216$, $P<0.0001)$ in the mean longevity of females exposed to the different concentrations of all insecticides.

The mean longevity was no significantly different among the treatments of $\mathrm{LC}_{501}, \mathrm{LC}_{51} / 2$ and $\mathrm{LC}_{50} / 5$ of imidaclopid $(P>0.05)$ and pymetrozine $(P>0.05)$, and among the treatments of $\mathrm{LC}_{51} / 5, \mathrm{LC}_{50} / 10$ of lufenuron and acetone $(P>0.05)$.

\section{DISCUSSION}

Beneficial arthropods can be exposed to pesticides by direct contact, by indirect contact with residues on plant surfaces, or by the ingestion of pesticide-contaminated prey or host (Jepson, 1989). In most studies, pesticide effects have been evaluated by exposure of the natural enemy to a range of pesticide concentrations (Desneux et al., 2004; Youn et al., 2003; Sanon et al., 2002; Akol et al., 2002, Yokoyama, 1984).

The females of $N$. formosa were very susceptible to imidaclopid, and its $\mathrm{LC}_{501}$ value was very low $(0.033 \mu \mathrm{g} / 0.5 \mathrm{ml})$. The $\mathrm{LC}_{501}$ values allowed to rank the insecticides in order of increasing toxicity: pymetrozine, lufenuron, imidacloprid. Imidacloprid was about 2290 times more toxic than pymetrozine. Moreover, the $\mathrm{LC}_{5 i}$ values were lower than recommended field rates for imidacloprid and lufenuron. When testing commercial products, the ratio between the field recommended rate and $\mathrm{LD}_{50}$ (or $\mathrm{LC}_{50}$ ) gives an indication of the risk (Youn et al., 2003; Desneux et al., 2004). Desneux et al. (2004) used this quotient for evaluating the risk of pesticides to Aphidius ervi, a generalist parasitoid of aphids.

Table 3. Effect of different doses of insecticides on longevity of $N$. formosa females. (day, mean \pm SD)

\begin{tabular}{|c|c|c|c|}
\hline \multirow{2}{*}{ Dose } & \multicolumn{3}{|c|}{ Common name } \\
\hline & Imidacloprid & Pymetrozine & Lufenuron \\
\hline $\mathrm{LC}_{511}$ & $1.54 \pm 0.65 \mathrm{a}$ & $2.56 \pm 1.3 \mathrm{a}$ & $2.37 \pm 1.46 \mathrm{a}$ \\
\hline $\mathrm{LC}_{5,1} / 2$ & $2.44 \pm 1.99 \mathrm{ab}$ & $2.78 \pm 1.15 \mathrm{a}$ & $4.84 \pm 4.82 b$ \\
\hline $\mathrm{LC}_{: \Omega 1} / 5$ & $3.31 \pm 3.33 b$ & $3.68 \pm 1.25 \mathrm{~b}$ & $10.41 \pm 5.81 \mathrm{c}$ \\
\hline $\mathrm{LC}_{: x \mathrm{x}} / 10$ & $5.37 \pm 4.93 c$ & $3.7 \pm 1.44 \mathrm{~b}$ & $11.4 \pm 5.18 \mathrm{c}$ \\
\hline Acetone & $10.74 \pm 3.94 \mathrm{~d}$ & $10.74 \pm 3.94 \mathrm{c}$ & $10.74 \pm 3.94 \mathrm{c}$ \\
\hline
\end{tabular}

Means with the same letters within a column are not significantly different by Fisher's PLSD after one-way ANOVA, $P<0.05$. 
The ratios may also allow to compare the risk to $N$. formosa among three treated insecticides. The ratio was equal to 0.8 for pymetrozine, 14.9 for lufenuron, and 775.5 for imidacloprid, presenting the highest risk. Imidacloprid was the most harmful insecticide to the parasitoid because of high toxicity and risk.

Previous studies indicated the decline of parasitoid populations caused by imidacloprid, lufenuron and pymetrozine application at field recommended rates (Ozawa, et al., 1998; Côsoli et al., 2001; Rebek and Sadof, 2003; Rogers and Potter, 2003). This study was evidence for a range of possible trends in susceptibility to those insecticides at low concentrations in the laboratory. Statistical comparison of both cumulative survival and mean longevity suggested the presence of sublethal effects of the tested insecticides on N. formosa. Exposure to imidacloprid, lufenuron and pymetrozine led to a concentration -dependent decline in survival (Fig. 1). Increasing insecticide concentrations caused the high level of parasitoid mortality. A comparison of the survivorship curves suggested that the cumulative survival rapidly decreased after exposure to imidacloprid for $24 \mathrm{~h}$, pymetrozine and lufenuron (at $\mathrm{LC}_{50}$ and $\mathrm{LC}_{50} / 2$ ) for $48 \mathrm{~h}$. Meanwhile, the survivorship curves of females exposed to lufenuron at $\mathrm{LC}_{50} / 5$ and $\mathrm{LC}_{5,1} / 10$ shared patterns of stability and decline similar to those of the acetone control. The data indicated that pymetrozine and lufenuron at low concentrations $\left(\mathrm{LC}_{5,1} / 5\right.$ and $\left.\mathrm{LC}_{5 / 1} / 10\right)$ did not have acute effects on $N$. formosa females, though those chronic effects caused the females' mortality increased after $48 \mathrm{~h}$ exposure.

Those insecticides also appeared to elicit a concentration-dependent decline in the mean longevity of $N$. formosa females (Table 3). Longevity of the females was greatly reduced by both imidacloprid and pymetrozine, and did not exceed 5.4 days in imidacloprid treatments, 3.7 days in pymetrozine treatments, compared to 10.7 days in control treatment. This agrees with the finding by Stapel et al. (2000) that longevity in the parasitoid Microplitis croceipes adults exposed to extrafloral nectar of cotton treated with imidacloprid was reduced. The high activity of imidacloprid is brought about by its binding to nicotinergic acetylcholine receptors in the insect nervous system (Marquini et al., 2002). The precise mode of action of pymetrozine is unknown, but treated insects quickly stop feeding and die of starvation (Harrewijn and Kayser, 1997). Thus, imidacloprid and pymetrizine had chronic toxic to $N$. formosa resulted in the reduction of the parasitoid's longevity.

At low concentrations $\left(\mathrm{LC}_{51} / 5\right.$ and $\left.\mathrm{LC}_{50} / 10\right)$, lufenuron did not affect longevity in $N$. formosa females. Since lufenuron works as a chitin- synthesis inhibitor by interfering with the synthesis of chitin, it causes parasitoid mortality before the parasitoid became a mature stage (Côsoli et al., 2001). The interference is perhaps not expected in this study since chitin synthesis is absent or occurs at a very low level in adults (Wilson and Cryan, 1997). It demonstrated that lufenuron at low concentrations was less toxic to the females.

The results of the present study suggest that a ranking system based on actual and chronic effects of treated insecticide toxicity on $N$. formosa was in the following relative order: imidacloprid $>$ pymetrozine $>$ lufenuron. In addition to chronic effects of these insecticides, a previous study showed that imidacloprid and lufenuron reduced host searching efficiency of $N$. formosa females (Tran et al., 2004). As a result, the treated insecticides are potential constraints on the effectiveness of $N$. formosa as a biological 
control agent of leafminers. However, both studies were conducted in the laboratory conditions, and thus tested insecticides are expected to be less harmful when apply in the field conditions.

\section{ACKNOWLEDGMENTS}

We thank Mr. Hiroyuki Takemoto (Fukuoka Agricultural Rearch Center) for providing $N$. formosa. We also thank Ms. Y. Ayabe and Mr. M. Uefune for practical assistance in rearing insects and applying insecticides.

\section{REFERENCES}

Akol, A. M., S. Sithanantham., P. G. N. Njagi., A. Varela and J. M. Mueke 2002 Relative safety of sprays of two neem insecticides to Diadegma mollipla (Holmgren), a parasitoid of the diamondback moth: effects on adult longevity and foraging behaviour. Crop Protection, 21(9): 853-859

Arakaki, N. and K. Kinjo 1998 Notes on the parasitoid fuuna of the serpentine leafminer Liriomyza trifolii (Burgess) (Diptera: Agromyzidae) in Okinawa, Southern Japan. Appl. Entomol. Zool., 33: $577-581$

Bethke, J. A. and R. A. Redak 1997 Effect of imidacloprid on the silverleaf whitefly, Bemisia argentifolii (Bellows and Perring) (Homoptera: Aleyrodidae), and whitefly parasitism. Ann. Appl. Biol., 130: $397-407$

Butter, N. S., G. Singh and A. K. Dhawan 2003 Laboratory evaluation of the insect growth regulator lufenuron against Helicoverpa armigera on cotton. Phytoparasitica, 31: 200-203

Croft, B. A. 1990 Arthropod Biological Control Agents and Pesticides. John Viley and Sons. New York, NY

Côsoli, F. L., P. S. M. Bottelho and J. R. P. Parra 2001 Selectivity of insecticides to the egg parasitoid Trichogramma galloi Zucchi, 1988, (Hym., Trichogrammatidae). J. Appl. Ent., 125: 37-43

Desneux, N., H. Rafalimanana and L. Kaiser 2004 Dose- response relationship in lethal and behavioural effects of different insecticides on the parasitic wasp Aphidius ervi. Chemosphere, 54(5): 619-627

Edomwande, E. O., A. S. Schoeman., J. A. Brits and M. van der Merwe 2000 Laboratory evaluation of lufenuron on immature stages of potato tuber moth (Lepidoptera: Gelechiidae). J. Econ. Entomol., 93: $1741-1743$

Ester, A., H. de Putter and J. G. P. M. van Bilsen 2003 Filmcoasting the seed of cabbage (Brassica oleracae L. convar. Capitata L.) and cauliflower (Brassia oleracae L. var. Botrytis L.) with immidaclopid and spinosad to control insect pests. Crop Prot., 22: 761-768

Giang H. T. T. and T. Ueno 2002 Biology of Hemiptarsenus varicomis (Hymenoptera: Eulophidae), a parasitoid wasp of the leafminer Liriomyza trifolli (Diptera: Agromyzidae). J. Fac. Agr., Kyushu Univ., 47(1): 45-54

Greathead, D. J. 1995 Natural enemies in combination with pesticides for integrated pest management. In "Novel Approaches to Integrated Pest Management", ed. by R. Reuveni, CRC Press. Boca Raton, FL, pp. 183-197

Harrewijn, P. and H. Kayser 1997 Pymetrozine, a fast-acting and selective inhibitor of aphid feeding. In-situ studies with electronic monitoring of feeding behaviour. Pesticide Sci., 49(2): 130-140

Hassan, S. A. 1989 Testing methodology and the concept of the IOBC/WPRS working group. In "Pesticides and Non-target Invertebrates", ed. by P. C. Jepson, Intercept, Hants, pp. 1-18

Hasson, C. 1990 A taxonomic study on the palearctic species of Chrysonotomyia Ashmead and Neochrysocharis Kurdjumov (Hymenoptera: Eulophidae). Ent. Scand., 21: 29-52

Hasson, C. 1995 Revision of the Nearctic species of Neochrysocharis Kurdjumov (Hymenoptera: Eulophidae). Ent. Scand., 26: 27-46

Javaid, I., R. N. Uaie and J. Massua 1999 The use of insect growth regulators for the control of insect pests of cotton. Int. J. Pest Manage., 45: 245-247

Jepson, P. C 1989 Pesticides and Non-target Invertebrates. Intercept, Andover Hants, UK

Johnson, M. W. and B. E. Tabashinik 1999 Enhanced biological control through pesticide selectivity. In 
"Handbook of Biological Control", ed. by Bellows, T. S., T. W. Fisher., L. E. Caltagirone., D. L. Dahlsten., C. Huffaker and G. Gordh, Academic Press, San Diego, CA, pp. 279-317.

Konishi, K. 1998 An illustrated key to the Hymenoptera parasitoids of Liriomyza trifolii in Japan. Misc. Publ. Agro-Environ. Sci., 22: 27-76 (in Japanese)

Marquini, F., R. N. C. Guedes., M. C. Picanço and A. J. Regazzi 2002 Response of arthropods associated with the canopy of common beans subjected imidacloprid spraying. J. Appl. Ent., 126: 550-556

Maryana, N. 2000 Studies on the ecological aspects of Neochrysocharis formosa (Hymenoptera: Eulophidae) attacking Liriomyza trifolii (Diptera: Agromyzidae). PhD thesis, Kyushu University, Japan

Ohno, K., T. Ohmori and H. Takenmoto 1999 Effect of insecticides applications and indigenous parasitoids on population trends of Liriomyza trifolii in gerbera greenhouses. Jpn. J. Appl. Entomol. Zool., 43: 81-86 (in Japanese with English summary)

Ozawa, A., T. Saito and F. Ikeda 1998 Effects of pesticides on Diglypus isaea (Walker) and Dacnusa sibirica Tenlenga, parasitoids of Liriomyza trifolii (Burgess). Jpn. J. Appl. Entomol. Zool., 42(3): 149-161 (in Japanese with English summary)

Parrella, M. P. and V. P. Jones 1987 Development of integrated pest management strategies in floricultural crops. Bull. Entomol. Soc. Am., 33: 28-34

Rebek, E. J. and C. S. Sadof 2003 Effects of pesticide applications o the Euonymus scale (Homoptera: Diaspididae) and its parasitoid, Encarsia citrina (Hymenoptera: Aphelinidae). J. Econ. Entomol., 96(2): 446-452

Rogers, M. E. and D. A. Potter 2003 Effects of spring imidacloprid application for white grub control on parasitism of Japanese beetle (Coleoptera: Scarabaeidae) by Tiphia vernalis (Hymenoptera: Tiphiidae). J. Econ. Entomol., 96(5): 1412-1419

Ruberson, J. R., H. Nemoto and Y. Hirose 1998 Pesticides and conservation of natural enemies in pest management. In "Conservation Biological Control", ed by P. Barbosa, Academic Press, New York, pp. 207-220

Saito, T., F. Ikeda and A. Ozawa 1996 Effect of pesticides on parasitoid complex of serpentine leafminer Liriomysa trifolii (Burgess) in Shizuoka Prefecture. Jpn. J. Appl. Entomol. Zool., 40: 127-133 (in Japanese with English summary)

Sakuma, M. 1998 Probit analysis of preference data. Appl. Entomol. Zool., 33: 339-347

Sanon, A., M. Garba., J. Auger and J. Huignard 2002 Analysis of the insecticidal activity of methylisothiocyanate on Callosobruchus maculatuc (F.) (Coleoptera: Bruchidae) and its parasitoid Dinarmus basalis (Rondani) (Hymenoptera: Pteromalidae). J. Stored Product Res., 38: 129-138

Sechser, B., B. Reber and F. Bourgeois 2002 Pymetrozine: Selectivity spectrum to beneficial arthropods and fitness for integrated pest management. J. Pest Sci., 75: 72-77

Sibanda, T., H. M. Dobson., J. F. Cooper., W. Manyangarirwa and W. Chiiba 2000 Pest management challenges for smallholder vegetable farmers in Zimbabwe. Crop Prot., 19: 807-815

Spencer, K. A. 1989 Leafminers. In "Plant Protection and Quarantine" Vol. 2, Selected pests and pathogens of quarantine significance, ed by Kahn, P. R, CRC Press, Boca Raton, FL, USA, pp. 77-98

Spencer, K. A. 1990 Host specialization in the world Agromyzidae (Diptera). Series Entomologica, Kluwer Ac. Pub, Dordrecht

Stapel, J. O., A. M. Cortesero and W. J. Levis 2000 Disruptive sublethal effects of insecticides on biological control: Altered foraging activity and life span of a parasitoid after feeding on extrafloral nectar of cotton treated with systemic insecticides. Biol. Control, 17: 243-249

Tran, D. H., M. Takagi and K. Takasu 2004 Effects of selective insecticides on host searching and oviposition behavior of Neochrysocharis formosa (Westwood) (Hymenoptera: Eulophidae), a parasitoid of the American serpentine leafminer. Appl. Entomol. Zool., 39(3): 435-441

van Lenteren, J. C. 2000 A greenhouse without pesticides: fact or fantasy? Crop Prot., 19: 375-384

Waterhouse, D. F. and K. R. Norris 1987 Liriomyza species (Diptera: Agromyzidae) leafminers. In "Biological control: Pacific prospects", ed by D. F. Waterhouse and K. R. Norris, Inkata Press, Melbourne, Australia, pp. 159-176

Whiting, D. C., L. E. Jamieson and P. G. Connolly 2000 Pre- and postharvest effects of lufenuron on Epiphyas postvittana (Lepidoptera: Tortricidae). J. Econ. Entomol., 93: 673-679

Wilson, T. G and J. R. Cryan 1997 Lufenuron, a chitin -synthesis inhibitor, interrupts development of Drosophila melanogaster. J. Exp. Zool., 278: 37-44 
Yokoyama, V. Y., J. Britchard and R. V. Dowell 1984 Laboratory toxicity of pesticides to Geocoris pallens (Hemiptera: Lygaeidae), a predator on California cotton. J. Econ. Entomol., 77: 10-15

Yoshimoto, C. M. 1978 Revision of subgenus Achrysocharella Girault of America North of Mexico (Chalcidoidea, Eulophidae: Chrysonotomyia Ashmead). Can. Ent., 110: 697-719

Youn, Y. N., M. J. Seo., J. G. Shin., C. Jang and Y. M. Yu 2003 Toxicity of greenhouse pesticides to multicolored Asian lady beetles, Harmonia axyridis (Coleoptera: Coccinellidae). Biol. Control, 28 (2): $164-170$ 